\title{
Environmental factors that determine the occurrence and seasonal dynamics of Aphanizomenon flos-aquae
}

\author{
Yoshimasa YAMAMOTO \\ Division of Applied Biosciences, Graduate School of Agriculture, Kyoto University, Kyoto 606-8502, Japan \\ Present address: Research Center for Environmental Changes, Academia Sinica, 128, Sec. 2, Academia Rd., Taipei 11529, Taiwan \\ e-mail: yyama@rcec.sinica.edu.tw
}

\begin{abstract}
This study investigated the seasonal dynamics of two populations of Aphanizomenon flos-aquae Ralfs ex Bornet \& Flahault var. flos-aquae and four populations of A. flos-aquae var. klebahnii Elenkin in eutrophic water bodies over 1 year from February 2006 to January 2007. The growth of A. flos-aquae var. flos-aquae was promoted at high temperatures even if in one case the biomass development was very low when other co-occurring cyanoprokaryotes (Anabaena spp. and Microcystis spp.) were abundant. In contrast, the highest density of the other population of A. flos-aquae var. flos-aquae was observed in August when the population density of M. aeruginosa (Kützing) Kützing reached an annual peak. A. flos-aquae var. flos-aquae usually bloomed in summer but could also tolerate low temperatures in the winter, and was present in relatively high densities. The populations of A. flos-aquae var. klebahnii observed in this study can be divided into three groups based on preferred temperature; three populations increased in winter, and the other increased in summer. Large biomasses of the low-temperature-adapted A. flos-aquae were observed mainly during winter when population densities of co-occurring cyanoprokaryotes (Anabaena spp., Microcystis spp. and Planktothrix raciborskii (Woloszynska) Anagnostidis \& Komárek) were relatively low or almost absent. The increase in or existence of cooccurring cyanoprokaryotes during the summer resulted in a decrease of the A. flos-aquae population density. It was revealed that high temperatures $\left(20-25^{\circ} \mathrm{C}\right)$ are suitable for maintaining A. flos-aquae var. klebahnii strains isolated from the study ponds, implying that low-temperature-adapted A. flos-aquae can grow over a wide range of water temperatures. The high-temperatureadapted A. flos-aquae var. klebahnii co-existed with M. aeruginosa during summer; however, its peak population density was significantly lower than those in previous years when M. aeruginosa was absent. Overall, analytical results imply a possible adverse impact of the existence of other cyanoprokaryotes, such as Anabaena and Microcystis, on both varieties of A. flos-aquae; however, its mechanism remains unknown. Nutrient concentrations and $\mathrm{pH}$ had no clear impact on the population density of A. flos-aquae. Based on these observations, progress of eutrophication and absence of other cyanoprokaryotes are likely the key factors determining the future expansion of A. flos-aquae.
\end{abstract}

Key words: cyanoprokaryote bloom, interspecific interaction, co-occurring cyanoprokaryotes

\section{INTRODUCTION}

Aphanizomenon is a common bloom-forming cyanoprokaryotic genus existing in eutrophic freshwater ecosystems and recently the number of the reports on its appearance is growing (Pollingher et al. 1998; Tsujimura et al. 2001; Yamamoto \& Nakahara 2005, 2006). Aphanizomenon has physiologically distinctive features, which seem to, at least partly, contribute to its expansion. It is worth notifying here, that Aphanizomenon produces akinetes in its life cycle. These cells arise from normal vegetative cells in response to environmental stresses, such as low phosphorus concentration, declines in temperature and low light intensity; they help therefore to promote survival in periods of unfavorable growth conditions (Lee 1999; Yamamoto \& Nakahara 2007). Vegetative cells typically arise from akinetes when adequate conditions reappear. Therefore, akinetes can be regarded as resting spores; thus, Aphanizomenon can exist in a wide range of environments as akinetes. Moreover, the ability of Aphanizomenon to generate another differentiated cell type, called a heterocyte is also noteworthy considering the competitive strategy of Aphanizomenon. The $\mathrm{N}_{2}$ molecules taken in by heterocytes are converted into $\mathrm{NH}_{4}{ }^{+}$, which is utilized for synthesis of amino acids (Lee 1999). Nitrogen often becomes a growth-limiting factor for photosynthetic plankters; thus, the ability to fix nitrogen contributes greatly to the propagation of general heterocystous cyanoprokaryotes.

Aphanizomenon has developed remarkable survival strategies and often forms blooms, especially at high latitudes. However, its appearance at lower latitudes is less frequent than that of other cyanoprokaryotes genera, such as Microcystis and Anabaena. Microcystis do not produce akinetes or heterocytes; however, this genus is very adaptable and frequently becomes the dominant organism as eutrophicasion progresses. Microcystis has developed effective nutrient-uptake capacities, such as a high affinity for dissolved inorganic nitrogen (Takamura et al. 1987), the storage of large amounts of phosphorus as polyphosphate (Jacobson \& Halmann 1982), direct uptake of phosphorus from fish gut (Lewin et al. 2003) and attached bacteria (Jiang et al. 2007). Moreover, its 
Tab. 1. Basic characteristics of the study fields and the occurrence of varieties of $A$. flos-aquae.

\begin{tabular}{lccccc}
\hline & \multirow{2}{*}{\begin{tabular}{c} 
Surface area \\
\cline { 3 - 4 }$\left(\mathrm{km}^{2}\right)$
\end{tabular}} & \multicolumn{2}{c}{ Depth $(\mathrm{m})$} & \\
\cline { 3 - 4 } & & maximum & mean & & A.flos-aquae \\
\hline Lake Biwa (southern basin) & $670(52)$ & $104(7)$ & $41.2(3.5)$ & & var. flos-aquae \\
Lake Yogo & 1.7 & 13.5 & 7.4 & & var. flos-aquae \\
Hirosawa-no-ike Pond & 0.14 & 1.8 & 1.0 & var. klebahnii \\
Osawa-no-ike Pond & 0.038 & $<3$ & $<2$ & & var. klebahnii \\
Benkei-ike Pond & 0.0053 & $<2$ & $\sim 1$ & & var. klebahnii \\
KU Pond & 0.000026 & 1.7 & 1.7 & & var. klebahnii \\
\hline
\end{tabular}

preference for low concentrations of dissolved inorganic carbon (Nakano et al. 2003), tolerance of strong irradiance (Paerl et al. 1985), ability to adjust cell buoyancy in response to light intensity and occupy the best position for photosynthesis (Ibelings et al. 1991), negative impact on filter-feeding cladocerans (Nizan et al. 1986), and overwintering in the form of vegetative cells (with no need to produce resting spores) (Preston et al. 1980) are all important to the ecological superiority of Microcystis. Although such characteristics contribute to bloom formation of Microcystis, whether some of these characteristics serve as critical factors enabling Microcystis to exist in the water more commonly than Aphanizomenon remains unknown because available comparable data for certain physiological parameters of both genera are lacking. Conversely, Anabaena has the same ecological strategies as Aphanizomenon; a recent molecular biological study demonstrated that these two genera are extremely similar (Gugger et al. 2002). Anabaena is a cosmopolitan genus found from tropical to subarctic regions; thus, the higher prevalence of Anabaena than of Aphanizomenon probably is related to qualitative differences in physiology, such as nutrient uptake activity and stress tolerance. Kinetic studies showed that Anabaena sp. had a higher maximum specific growth rate than Aphanizomenon flos-aquae (L.) Ralfs and had a higher phosphorus uptake ability, whereas the ability to adapt to light-limiting conditions was higher in Aphanizomenon flos-aquae (De Nobel et al. 1997, 1998). Although Livingstone \& Jaworski (1980) germinated 64-year-old Anabaena akinetes, whether the life span of Aphanizomenon akinetes is as long as those of Anabaena remains unknown, even though Aphanizomenon akinetes can survive for at least 18 years. The long-term viability of akinetes may provide opportunities to become a component in plankton community and, thus, the long-term viability of Anabaena would be more advantageous than that of Aphanizomenon.

Explaining the relative low frequency of Aphanizomenon blooms based on previous studies is indeed difficult. However, the first appearance of Aphanizomenon in several lakes (Jacobsen 1994; Breukers et al. 1997; Pollingher et al. 1998; Tsujimura et al. 2001) may be attributed to changes in the aquatic environment. Investigating the factors that provide a new ecological niche for Aphanizomenon is valuable based on the ecology of cyanoprokaryotes and predictions of the future expansion of Aphanizomenon. This study elucidates how environmental factors affect the occurrence of two populations of A. flos-aquae Ralfs ex Bornet \& Flahault var. flos-aquae and four populations of $A$. flos-aquae var. klebahnii Elenkin that have appeared in six freshwater ecosystems.

\section{METHODS}

\subsection{Morphological characteristics of the two varieties of A. flos-aquae}

A. flos-aquae var. flos-aquae often exists as large fascicle-like colonies, typically composed of several dozen straight trichomes. In contrast, A. flos-aquae var. klebahnii exists as solitary trichomes and never aggregates. The single trichomes of these species are very similar; however, A. flos-aquae var. flos-aquae trichomes generally consist of large vegetative cells, akinetes and heterocytes (Komárek \& Kováčik 1989; Watanabe 1991; Pechar 1992).

\subsection{Study sites}

This study was performed at Lake Biwa, Lake Yogo, the Hirosawa-no-ike Pond, Osawa-no-ike Pond, Benkeiike Pond and a small artificial pond on the grounds of Kyoto University (KU Pond). Lake Biwa and Lake Yogo are located in Shiga Prefecture, central Japan; the other water bodies are located in Kyoto Prefecture (Fig. 1, Tab. 1). The water level of Lake Yogo is reduced during summer for irrigation. Some of the water inflowing into Lake Biwa travels through the Yogo River. Conversely, Lake Yogo receives inflow from Lake Biwa via an artificial water pump system that refills Lake Yogo (Tsujimura 2004; Tsukada et al. 2006). The Hirosawa-no-ike Pond is used for irrigation and as a fish pond; its water level and water quality are markedly affected by the fishery. The pond is filled from mid-February to late November, and most pond sediment is exposed to air during other times. Water flows into the pond beginning in mid-February, and the Osawa-no-ike Pond is an important water source. The Benkei-ike Pond and KU Pond are closed systems, and serve as fishing pond and water for fire protection, respectively. 


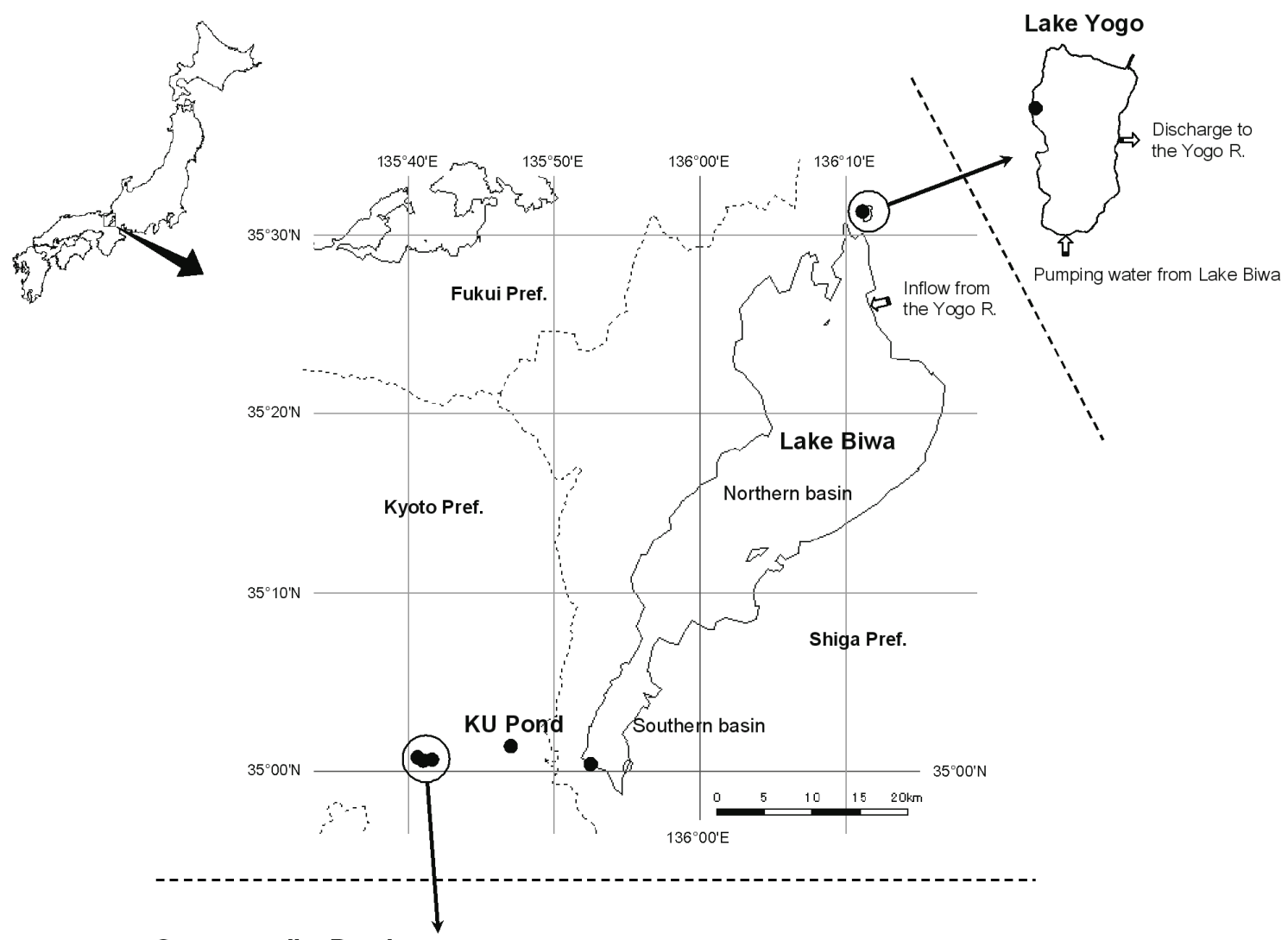

Osawa-no-ike Pond

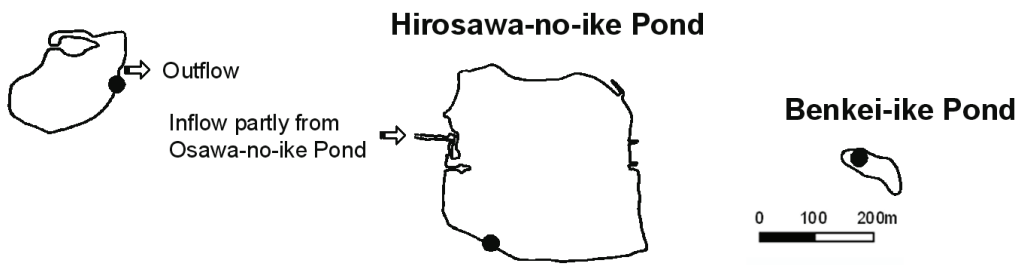

Fig. 1. Map showing the location of the study fields.

\subsection{Sampling and chemical measurements}

Water samples were collected monthly from Lake Biwa, Lake Yogo, the Benkei-ike Pond and KU Pond, and biweekly from the Hirosawa-no-ike Pond and Osawa-no-ike Pond, throughout seasons from February 2006 to January 2007. Temperature and $\mathrm{pH}$ were measured in situ using a mercury thermometer and a B-212 compact $\mathrm{pH}$ meter (Horiba, Ltd., Kyoto, Japan). The concentrations of $\mathrm{NO}_{3}{ }^{-} \mathrm{N}, \mathrm{NO}_{2}^{-}-\mathrm{N}, \mathrm{NH}_{4}{ }^{-}-\mathrm{N}$, and $\mathrm{PO}_{4}{ }^{3-}-$ $\mathrm{P}$ in samples filtered through a Whatman $\mathrm{GF} / \mathrm{C}$ filter were measured with a spectrophotometer (Shimadzu UV-1700, Kyoto, Japan) using the methods described by Mullin \& Riley (1955), Bendschneider \& Robinson (1952), Sagi (1966), and Murphy \& Riley (1962), respectively. Dissolved inorganic nitrogen (DIN) was determined as the sum of $\mathrm{NO}_{3}^{-}-\mathrm{N}, \mathrm{NO}_{2}^{-}-\mathrm{N}$ and $\mathrm{NH}_{4}{ }^{+}-\mathrm{N}$. Chlorophyll- $a$ concentrations in organisms trapped in filters were determined with a fluorometer (Turner Designs 10-AU 005, Sunnyvale, California, USA) after extraction in $90 \%$ acetone for 24 hours under darkness.

\subsection{Enumeration of organisms}

One hundred milliliter-water samples were fixed with Lugol's solution (final concentration 1\%) and sedimented. After 48 hours, $90 \mathrm{~mL}$ of supernatant was removed and sedimented organisms were poured into a test tube and again sedimented for 24 hours by adding 1 drop of Lugol's solution. The trichome or colony densities of cyanoprokaryotes in concentrated samples (1-10 $\mathrm{mL}$ ) were measured under an inverted microscope (Nikon ECLIPSE TE300, Tokyo, Japan) by diluting with distilled water when necessary. The biovolumes of A. flos-aquae were estimated by assuming their shapes were cylinders. 


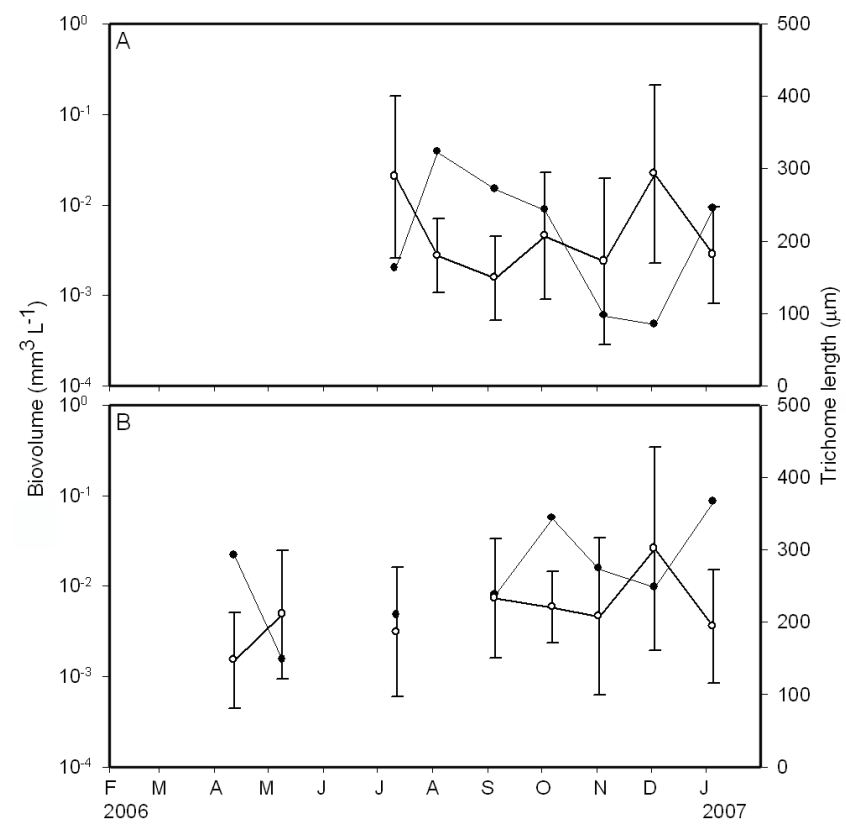

Fig. 2. Changes in biovolume (closed circles) and trichome length of A. flos-aquae (open circles, where error bars represent standard deviation) in Lake Biwa (A) and Lake Yogo (B).

\section{RESULTS}

\subsection{Seasonal dynamics of A. flos-aquae var. flos-aquae}

In Lake Biwa, relatively long trichomes $(289 \pm 112$ $\mu \mathrm{m})$ of $A$. flos-aquae were first detected in July (Fig. 2A). Biovolume peaked in August $\left(0.0383 \mathrm{~mm}^{3} \mathrm{~L}^{-1}\right)$ with small trichomes $(180 \pm 50.9 \mu \mathrm{m})$. Biovolume decreased starting in September, and then rapidly increased in January.

A. flos-aquae appeared in April-January in Lake Yogo; however, it was not detected in June and August (Fig. 2B). Mean trichome length was $147-301 \mu \mathrm{m}$. A. flos-aquae was dominant in January $\left(0.0854 \mathrm{~mm}^{3} \mathrm{~L}^{-1}\right)$.

\subsection{Seasonal dynamics of A. flos-aquae var. klebahnii}

A. flos-aquae existed in the Hirosawa-no-ike Pond in mid-February, and both biovolume and trichome length increased 2 weeks later (Fig. 3A). Biovolume markedly decreased through April, and was undetectable from May, but it reappeared in mid-October at a low density, and rapidly increased in November.

In the Osawa-no-ike Pond, A. flos-aquae also existed in February (Fig. 3B). The trichome length increased in mid-February, and then decreased at a rate of $1.38 \mu \mathrm{m}$ $\mathrm{d}^{-1}(r=-0.995, n=7, p<0.001)$ until mid-May. A. flosaquae disappeared from plankton by the end of May, but reappeared in September and a high level persisted after November.

The biovolume of $A$. flos-aquae in the Benkei-ike Pond decreased from $0.0727 \mathrm{~mm}^{3} \mathrm{~L}^{-1}$ to $0.0422 \mathrm{~mm}^{3} \mathrm{~L}^{-1}$ from February to April (Fig. 3C). A rapid increase in
May $\left(0.520 \mathrm{~mm}^{3} \mathrm{~L}^{-1}\right)$ was followed by a sharp decline, and A. flos-aquae disappeared from plankton in August. However, it reappeared in October; both biovolume and trichome length increased until December.

In contrast to the other ponds, A. flos-aquae in the KU Pond was first detected in May at a low density $\left(7.88 \times 10^{-4} \mathrm{~mm}^{3} \mathrm{~L}^{-1}\right)$ (Fig. 3D). The biovolume increased sharply in June and a high level (0.382-3.67 $\mathrm{mm}^{3} \mathrm{~L}^{-1}$ ) was maintained until September. Mean trichome length was $85.5-253 \mu \mathrm{m}$. The A. flos-aquae density was always below the detection limit after October.

\subsection{Physico-chemical conditions and co-occurring cyanoprokaryotes in waters in which $\mathrm{A}$. flos-aquae var. flos-aquae appeared}

The water temperature in Lake Biwa peaked at 30.0 ${ }^{\circ} \mathrm{C}$ in August, and decreased to $6.3{ }^{\circ} \mathrm{C}$ in January. The $\mathrm{pH}$ was generally constant (6.4-6.8) from February to May, but increased to 9.3 in July, and then fluctuated at 6.5-7.6 after August. The DIN concentration was high in early spring, thereafter decreased gradually to the minimum of $2.5 \mu \mathrm{mol} \mathrm{L}^{-1}$ in July. It rapidly increased to the maximum $\left(22.6 \mu \mathrm{mol} \mathrm{L}^{-1}\right)$ in September. The concentration of $\mathrm{PO}_{4}{ }^{3-}-\mathrm{P}$ peaked in September.

Both Anabaena and Microcystis appeared in May and were abundant in July-September. Anabaena was composed of four species - A. affinis Lemmermann, $A$. crassa (Lemmermann) Komárkova-Legnerová \& Cronberg, A. flos-aquae Brébisson ex Bornet \& Flahault, and A. macrospora Klebahn - whereas the proportions of $A$. affinis and $A$. macrospora were always $<10 \%$, except for in September when the former and latter accounted 


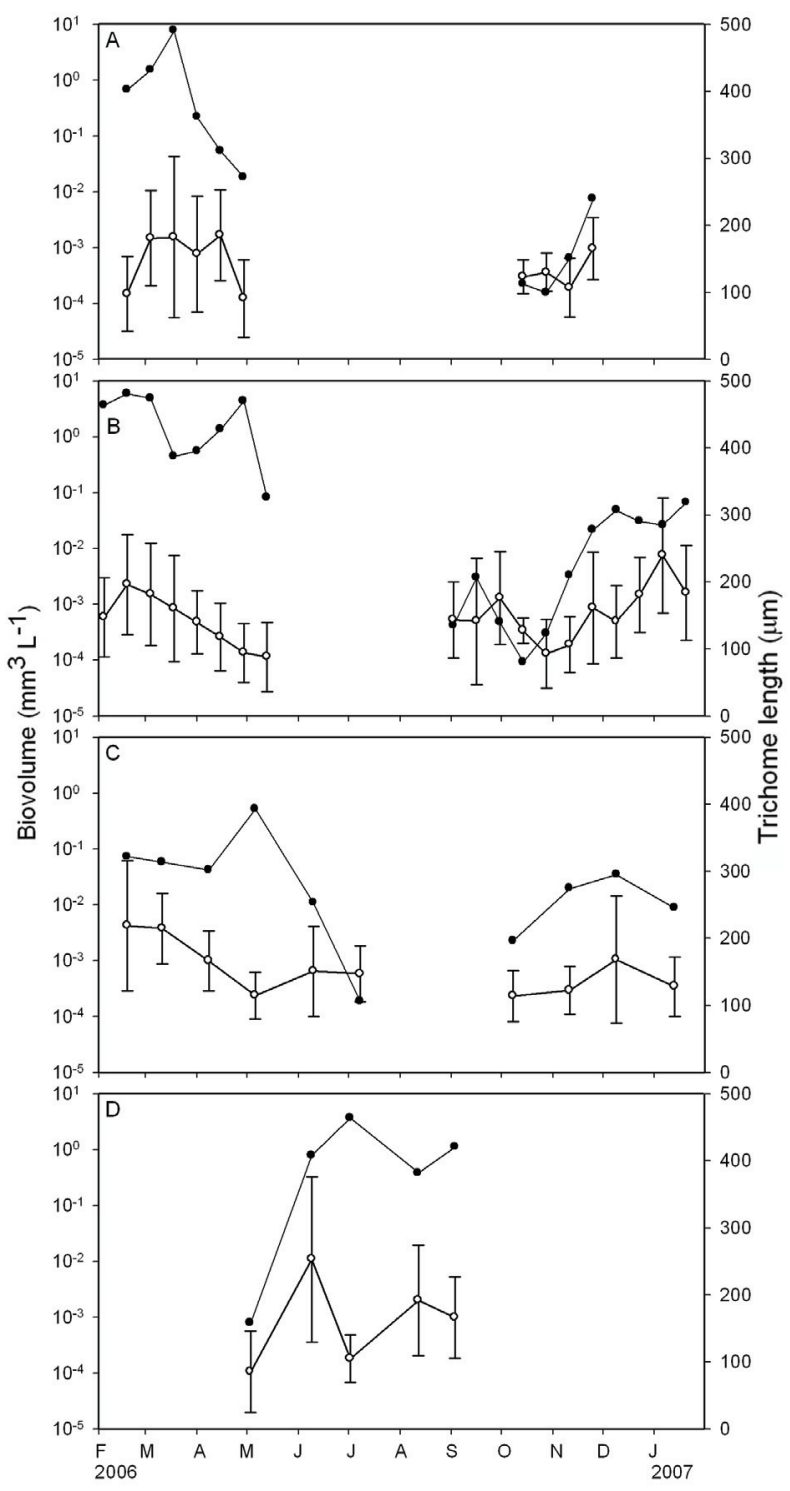

Fig. 3. Same as Fig. 2, but in Hirosawa-no-ike Pond (A), Osawa-no-ike Pond (B), Benkei-ike Pond (C) and KU Pond (D).

for $19.0 \%$ and $35.6 \%$, respectively. M. aeruginosa (Kützing) Kützing was the dominant species and accounted for $60-100 \%$ of all Microcystis species throughout the study period; $M$. wesenbergii (Komárek) Komárek comprised the remaining percentage. Oscillatoria kawamurae Negoro increased from after first emerging in June and reached 29.3 trichomes $\mathrm{mL}^{-1}$. Although densities were low, these cyanoprokaryotes were detected even in December.

The water temperature in Lake Yogo increased steadily and peaked at $29.7^{\circ} \mathrm{C}$ in August. The $\mathrm{pH}$ fluctuated at 6.5-8.9. The DIN concentration in March was $18.6 \mu \mathrm{mol} \mathrm{L}^{-1}$, but was below $2.9 \mu \mathrm{mol} \mathrm{L}-1$ after May. No clear seasonal variations existed in the concentration of $\mathrm{PO}_{4}{ }^{3-}$-P. Anabaena and Microcystis were detected for the first time in April at densities of 0.433 trichomes
$\mathrm{mL}^{-1}$ and 0.0167 colonies $\mathrm{mL}^{-1}$, respectively. The Anabaena density declined to a minimum $(0.130$ trichomes $\mathrm{mL}^{-1}$ ) in September, followed by a peak at 13.1 trichomes $\mathrm{mL}^{-1}$, and high densities remained until January. A. crassa and A. flos-aquae accounted for $>92 \%$ of Anabaena species, with the exception of June and July; A. macrospora appeared in June-December and accounted for $56.0 \%$ and $16.0 \%$ of all Anabaena species in June and July, respectively. Microcystis density peaked at 281 colonies $\mathrm{mL}^{-1}$ in August. The Microcystis species composed of $M$. aeruginosa and $M$. wesenbergii; the former accounted for $75.0-99.6 \%$ of the whole Microcystis, with the exception of December, when the latter accounted for $75.0 \%$. Planktothrix agardhii (Gomont) Anagnostidis \& Komárek existed during June-October intermittently with a maximum density of 0.15 trichomes $\mathrm{mL}^{-1}$.

\subsection{Physico-chemical conditions and co-occurring cyanoprokaryotes in waters in which A. flos-aquae var. klebahnii appeared}

The water temperature in the Hirosawa-no-ike Pond peaked at $34.8{ }^{\circ} \mathrm{C}$ in August. The $\mathrm{pH}$ fluctuated at $6.9-$ 9.8 from February to June; however, high values $(>9.0)$ lasted in July-October. The DIN concentrations often remained low $\left(<1.8 \mu \mathrm{mol} \mathrm{\textrm {L } ^ { - 1 }}\right)$; however, two rapid increases appeared in June $\left(24.4 \mu \mathrm{mol} \mathrm{L}^{-1}\right)$ and July $\left(43.8 \mu \mathrm{mol} \mathrm{L} \mathrm{L}^{-1}\right)$. The $\mathrm{PO}_{4}{ }^{3-}-\mathrm{P}$ concentrations were $0.176-5.44 \mu \mathrm{mol} \mathrm{L}^{-1}$. Anabaena was present constantly from late June. The maximum density of Anabaena was $1.10 \times 10^{4}$ trichomes $\mathrm{mL}^{-1}$, which was observed in early September. Four Anabaena species were identified: $A$. crassa, A. flos-aquae, A. macrospora, and A. reniformis Lemmermann. The mean proportions of $A$. crassa, $A$. flos-aquae and $A$. reniformis were $68.1 \%, 18.5 \%$ and $13.4 \%$, respectively, and the proportion of $A$. macrospora never exceeded $0.02 \%$ despite its continual existence during July-September. The population density of Microcystis decreased from early March to early April, but typically exceeded 1000 colonies $\mathrm{mL}^{-1}$ after late April. The main Microcystis species throughout the study period was $M$. aeruginosa; its proportion was $32.7-93.7 \%$ with an average of $71.5 \%$. The mean proportions of M. viridis and M. wesenbergii were $12.6 \%$ and $15.9 \%$, respectively. Planktothrix raciborskii (Woloszynska) Anagnostidis \& Komárek appeared for the first time in early June, and continually existed until January. Raphidiopsis mediterranea Skuja was observed continuously in August-November.

The water temperature in the Osawa-no-ike Pond reached $32.7{ }^{\circ} \mathrm{C}$ in early August and gradually decreased to $7.0{ }^{\circ} \mathrm{C}$ in January. The $\mathrm{pH}$ varied at 7.0-9.3, with a mean of $7.9 \pm 0.59$ (SD). Although some sporadic increases in nutrient concentrations were observed, these increases were generally constant for the remainder of the sampling period. The concentra- 
tions of DIN and $\mathrm{PO}_{4}{ }^{3-}-\mathrm{P}$ exhibited no clear seasonal change. The concentration of DIN fluctuated between 0 and $5.3 \mu \mathrm{mol} \mathrm{L}^{-1}$ with a mean $\pm \mathrm{SD}$ of $0.95 \pm 1.3 \mu \mathrm{mol}$ $\mathrm{L}^{-1}$. The concentration of $\mathrm{PO}_{4}{ }^{3-}-\mathrm{P}$ was typically $<0.5$ $\mu$ mol L ${ }^{-1}$, but sporadic increases $\left(>1.3 \mu \mathrm{mol} \mathrm{L}{ }^{-1}\right)$ were observed in April, September and December. Anabaena was observed during April-January, especially in April and late summer months (August and September). The species composition of Anabaena in the Osawa-no-ike Pond was identical to that in the Hirosawa-no-ike Pond, though the seasonal dynamics were different; the dominant species differed according to season, and each species became dominant at least once during the study period. Microcystis also occurred after May; however, its population density never exceeded 1 colonies $\mathrm{ml}^{-1}$. $M$. aeruginosa was the dominant species in MayAugust, whereas $M$. wesenbergii was dominant at some times after September.

The water temperature in the Benkei-ike Pond fluctuated between $6.2^{\circ} \mathrm{C}$ (February) and $28.9^{\circ} \mathrm{C}$ (August). The $\mathrm{pH}$ peaked in May (8.7) and October (8.7). Concentrations of DIN exceeded $21 \mu \mathrm{mol} \mathrm{L}^{-1}$ from February to April, but remained low $\left(0.19-3.2 \mu \mathrm{mol} \mathrm{L}^{-1}\right)$ until October, and then increased from November. Mean concentration of $\mathrm{PO}_{4}{ }^{3-}-\mathrm{P}$ was $0.33 \pm 0.034(\mathrm{SD}) \mu \mathrm{mol}$ $\mathrm{L}^{-1}$, with no clear seasonal variation. Anabaena $(A$. crassa and A. flos-aquae) was detected intermittently with a maximum density of 0.80 colonies $\mathrm{mL}^{-1}$. In contrast, Microcystis was observed throughout the study period. The population density of Microcystis was 5.20142 colonies $\mathrm{mL}^{-1}$, with a mean of 44.3 colonies $\mathrm{mL}^{-1}$. Notably, M. aeruginosa was often the most dominant species, accounting for $34.7-95.7 \%$ of all Microcystis species, followed by $M$. wesenbergii, which became dominant in October and November. Additionally, $M$. viridis comprised only a small proportion of Microcystis species $(0-2.1 \%)$.

The water temperature in the KU Pond ranged from $2.8^{\circ} \mathrm{C}$ (February) and $28.3{ }^{\circ} \mathrm{C}$ (August). A high pH (>8.6) lasted during April-August, followed by a reduction after October. The concentration of DIN peaked in July $\left(9.2 \mu \mathrm{mol} \mathrm{L}^{-1}\right)$ and reached a minimum $\left.(4.3 \mu \mathrm{mol} \mathrm{L})^{-1}\right)$ in September. It increased from October and reached a maximum $\left(16.3 \mu \mathrm{mol} \mathrm{L}^{-1}\right)$ in December. The $\mathrm{PO}_{4}{ }^{3-}-\mathrm{P}$ concentration was always below the detection limit. The sole co-occurring cyanoprokaryote was M. aeruginosa, which was detected in May-January; its maximum density was 75 colonies $\mathrm{mL}^{-1}$ (September).

\subsection{Relationship between A. flos-aquae biovolume and environmental factors}

Figures 4 and 5 and table 2 show relationships between biovolume of A. flos-aquae and environmental factors. A. flos-aquae in Lake Biwa and Lake Yogo appeared over wide ranges of water temperature and $\mathrm{pH}$. Biovolumes of $A$. flos-aquae in Lake Biwa and Lake Yogo were not significantly correlated with envi- ronmental factors, except for a positive correlation with the population density of $O$. kawamurae in Lake Biwa. Biovolumes of A. flos-aquae in Hirosawa-no-ike Pond and Osawa-no-ike Pond were negatively correlated with water temperature and the abundance of co-occurring cyanoprokaryotes such as Microcystis and Anabaena. In contrast, the biovolume of A. flos-aquae in KU Pond tended to increase with water temperature and the abundance of Microcystis, although the correlations were not statistically significant. A. flos-aquae appeared in the KU Pond at $\mathrm{pH}$ values of above 7.9 , whereas $A$. flosaquae was present in the other three ponds over a wide range of $\mathrm{pH}$ values. A. flos-aquae was present in Benkei-ike Pond almost independently of all environmental conditions. Overall, A. flos-aquae biovolumes were not clearly related to $\mathrm{pH}$ or nutrient concentration.

\section{DISCUSSION AND CONCLUSIONS}

All lakes and ponds in this study had water qualities safely classified as eutrophic, implying that eutrophication of freshwater ecosystems can provide A. flos-aquae with opportunities for growth, which is consistent with general beliefs. However, the dominant variety of $A$. flos-aquae differed among ecosystems; A. flos-aquae var. flos-aquae appeared in Lake Biwa and Lake Yogo, whereas A. flos-aquae var. klebahnii was the dominant variety in other aquatic systems. Notably, the waters in which A. flos-aquae var. flos-aquae appeared were considerably larger and deeper than those in which $A$. flosaquae var. klebahnii existed. Water body depth is strongly related to the degree of thermal stratification, which is of particular importance when determining the vertical distribution of phytoplankton. However, severe thermal stratifications are unlikely to form in the water bodies in this study, due to relatively shallow depths, including the southern basin of Lake Biwa, and aeration system in Lake Yogo (Tsujimura 2004). An attempt to generalize the correlation between the occurrence of either variety of $A$. flos-aquae and size of a water body will, however, fail, as A. flos-aquae var. flos-aquae has been identified in water bodies with surface areas that are smaller than that of the Hirosawa-no-ike Pond and A. flos-aquae var. klebahnii has been observed in the water bodies with surface areas larger than that of Lake Yogo (Ganf 1983; Pechar 1992; Breukers et al. 1997). As a selective force in determining the dominant variety of A. flos-aquae, Pechar (1992) noted the role of large cladoceran Daphnia; they may change the underwater light environment by reducing the small-sized phytoplankton including solitary trichomes of $A$. flos-aquae var. klebahnii, which consequently provide an opportunity for development of the large aggregates of A. flosaquae var. flos-aquae. Conversely, the absence of Daphnia is favored by A. flos-aquae var. klebahnii. Lynch \& Shapiro (1981) and Ganf (1983) also pointed out the positive impact of $D$. pulex Leydig on the dominance of A. flos-aquae var. flos-aquae. Data presented 

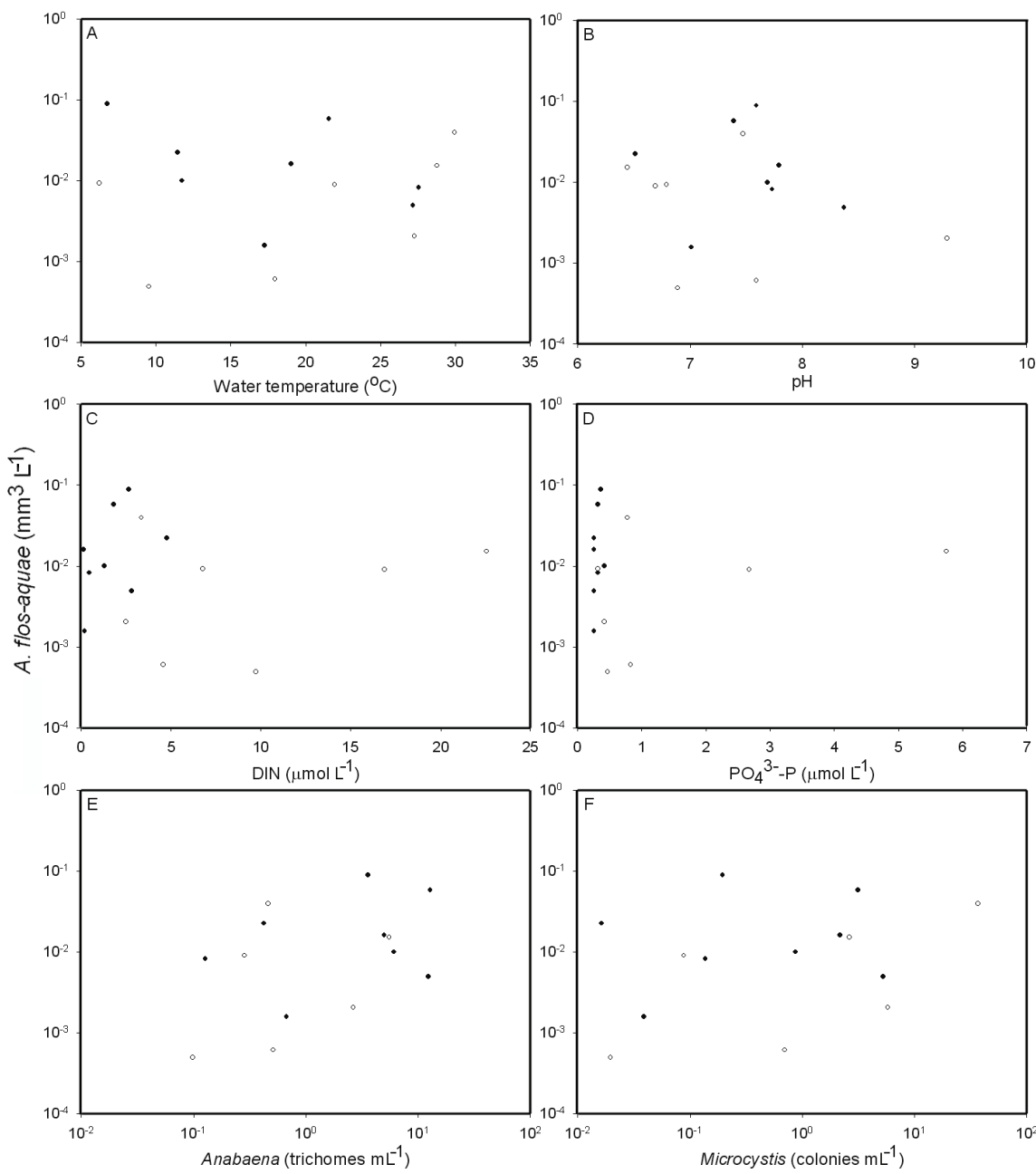

Fig. 4. Relationships between $A$. flos-aquae biovolume and water temperature (A), $\mathrm{pH}(\mathrm{B}), \mathrm{DIN}$ concentration $(\mathbf{C}), \mathrm{PO}_{4}{ }^{3-}-\mathrm{P}$ concentration (D), trichome density of Anabaena (E) and colony density of Microcystis (F) in Lake Biwa (open circles) and Lake Yogo (closed circles).

by Breukers et al. (1997) showing the frequent appearance of $A$. flos-aquae var. klebahnii especially after the disappearance of $D$. pulex may suggest a negative impact of $D$. pulex on the dominance of A. flos-aquae var. klebahnii. Moreover, D. pulex can graze on A. flosaquae var. flos-aquae as long as they exist as single trichomes or form small colonies $<1.5 \mathrm{~mm}$ (Holm et al. 1983). These observation results suggest that the existence of large cladocerans can be a critical factor in selecting the variety of $A$. flos-aquae in waters and in regulating $A$. flos-aquae seasonal dynamics. However, the primary components of zooplankton communities in the aquatic systems in this study were rotifers and/or small cladocerans; large cladocerans like Daphnia were always undetectable in concentrated water samples (data not shown). Therefore, in this study, the direct impact of large herbivorous zooplankton on A. flos-aquae was negated and the role of small zooplankton in a cyanoprokaryotic community was probably negligible due to their low feeding activities.
Notably, A. flos-aquae var. flos-aquae existed in both Lake Biwa and Lake Yogo almost throughout the entire year with a relatively high biomass in winter. Tsujimura et al. (2001) examined the growth response of A. flos-aquae var. flos-aquae isolated from Lake Biwa in a wide range of water temperatures $\left(5-32{ }^{\circ} \mathrm{C}\right)$, and demonstrated that the lowest temperature at which A. flos-aquae can grow is $8{ }^{\circ} \mathrm{C}$; optimum temperature range was $23-29{ }^{\circ} \mathrm{C}$. They also reported that $A$. flosaquae cultured at $5{ }^{\circ} \mathrm{C}$ for 25 days retained the ability to grow, indicating the possibility that the high population densities of A. flos-aquae in Lake Biwa and Lake Yogo during winter was due to its low-temperature tolerance rather than low-temperature preference. This physiological feature enables $A$. flos-aquae to exist during winter in high densities by accumulating at the surface (Tsukada et al. 2006).

In Lake Yogo, the A. flos-aquae biomass was low during summer when other populations of cyanoprokaryotes, such as Anabaena and Microcystis, increased. 

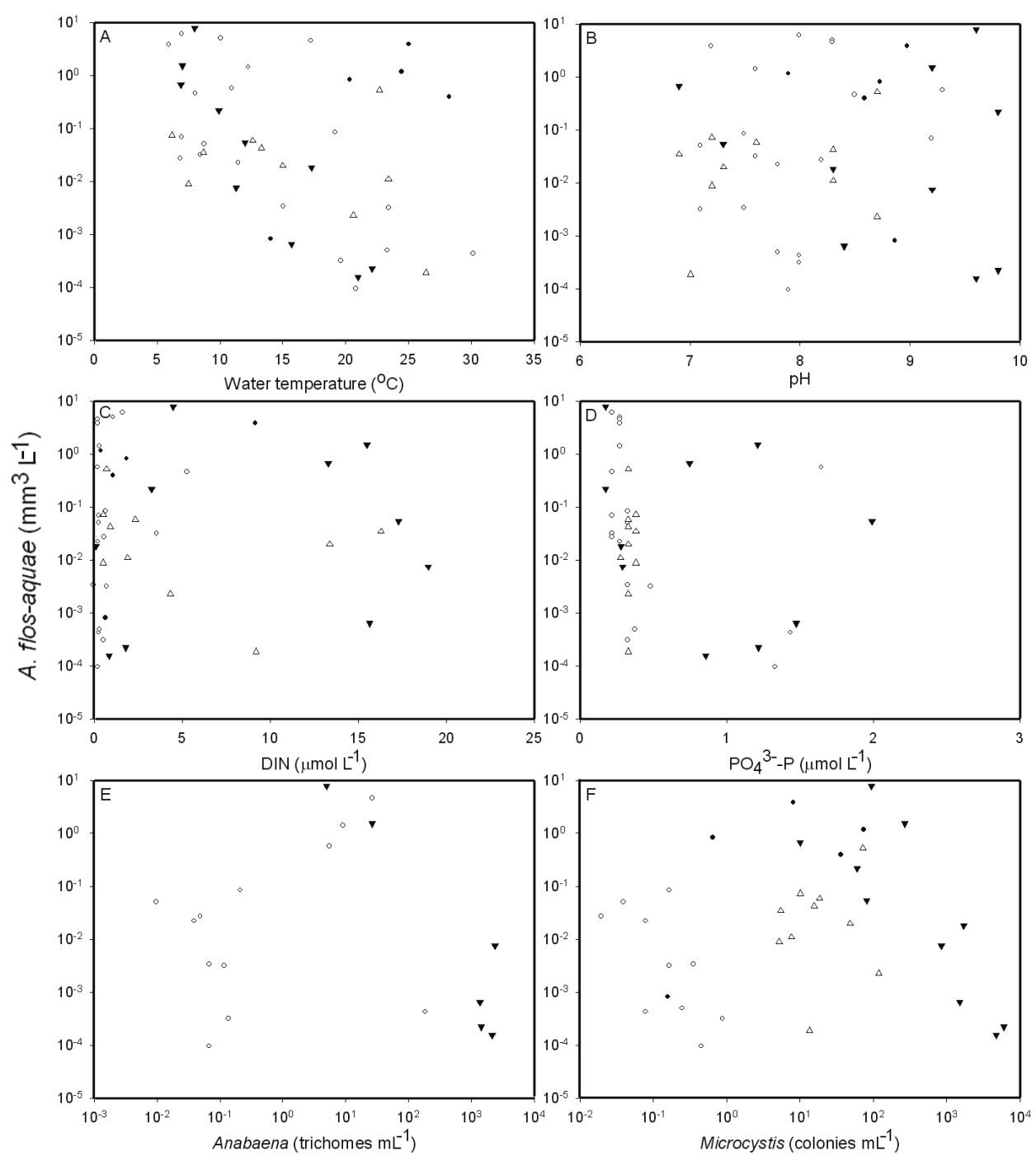

Fig. 5. Same as figure 4, but in Hirosawa-no-ike Pond (closed triangles), Osawa-no-ike Pond (open circles), Benkei-ike Pond (open triangles) and KU Pond (closed circles).

Tab. 2. Linear correlation coefficients between natural logarithm of A. flos-aquae biovolume and environmental factors in Lake Biwa (Biwa), Lake Yogo (Yogo), Hirosawano-ike Pond (Hiro), Osawa-no-ike Pond (Osa), Benkei-ike-Pond (Ben) and KU Pond (KU). Bold values are significant at the $5 \%$ level. The natural logarithms of the population densities of co-occurring cyanoprokaryotes are used to improve the fit.

\begin{tabular}{lcccccccc}
\hline & \multicolumn{2}{c}{ var. flos-aquae } & & \multicolumn{5}{c}{ var. klebahnii } \\
\cline { 2 - 3 } & Biwa & Yogo & & Hiro & & Osa & Ben & KU \\
\hline Water temperature & 0.48 & -0.43 & & $\mathbf{- 0 . 9 1}$ & $\mathbf{- 0 . 6 8}$ & -0.41 & 0.80 \\
$\mathrm{pH}$ & -0.28 & -0.09 & & -0.19 & 0.20 & 0.27 & -0.25 \\
$\mathrm{DIN}$ & 0.27 & 0.42 & & 0.19 & 0.21 & 0.29 & 0.49 \\
$\mathrm{PO}_{4}{ }^{3-}-\mathrm{N}$ & 0.40 & 0.37 & & -0.30 & -0.36 & 0.15 & - \\
Anabaena & 0.38 & 0.30 & & $\mathbf{- 0 . 9 4}$ & 0.31 & - & - \\
Microcystis & 0.60 & 0.16 & & $\mathbf{- 0 . 8 2}$ & $\mathbf{- 0 . 6 6}$ & 0.09 & 0.68 \\
Oscillatoria & $\mathbf{0 . 9 4}$ & - & & - & - & - & - \\
Planktothrix & - & - & & 0.48 & - & - & - \\
Raphidiopsis & - & - & & 0.73 & - & - & - \\
\hline
\end{tabular}


The maximum temperature of $29.7^{\circ} \mathrm{C}$ in Lake Yogo is considered slightly higher than the optimum range for A. flos-aquae growth (Uehlinger 1981; Pechar 1992; Tsujimura et al. 2001). However, a decrease in the in situ population of $A$. flos-aquae had already occurred in May when water temperature was $17.3{ }^{\circ} \mathrm{C}$, suggesting that high temperature itself is not a main causative factor for the disappearance of A. flos-aquae during summer. In fact, some studies reported the dominance of $A$. flos-aquae during summer (Jones 1979; Pechar 1992; Takano \& Hino 2000). One possible factor determining the biomass of $A$. flos-aquae during summer is the existence of other cyanoprokaryotes. An inverse relationship between population densities of A. flos-aquae and other cyanoprokaryotes, such as Anabaena, Microcystis and Oscillatoria, during summer (Lynch \& Shapiro 1981; Hino 1992; Shapiro 1997; Tsukada et al. 2006) suggests an existence of an interference interaction between A. flos-aquae and other cyanoprokaryotes. Due to the low-frequency survey and intermittent absence of A. flos-aquae, no significant correlation existed between population densities of $A$. flos-aquae and cooccurring cyanoprokaryotes in Lake Yogo. However, if the decrease in the $A$. flos-aquae population is related to the existence of other cyanoprokaryotes, they can suppress $A$. flos-aquae with very low densities; the population densities of A. flos-aquae, Anabaena and Microcystis in May, when the density of A. flos-aquae declined sharply, were 0.40 trichomes $\mathrm{mL}^{-1}, 0.69$ trichomes $\mathrm{mL}^{-1}$ and 0.040 colonies $\mathrm{mL}^{-1}$, respectively.

In Lake Biwa, the peak biomass of $A$. flos-aquae var. flos-aquae occurred at the same time as those of Anabaena, Microcystis and O. kawamurae. This observation result is inconsistent with that for Lake Yogo. The population densities of Anabaena and Microcystis in Lake Biwa were usually lower than those in Lake Yogo, engendering a possibility that $A$. flos-aquae var. flos-aquae can grow without being affected severely by low densities of co-occurring cyanoprokaryotes. However, co-occurring cyanoprokaryotes likely had negative impacts on the A. flos-aquae population in Lake Biwa, as inferred by the rapid increase in A. flos-aquae in January when other cyanoprokaryotes were absent.

The appearance of $A$. flos-aquae var. klebahnii during winter was typical in the Hirosawa-no-ike Pond, Osawa-no-ike Pond and Benkei-ike Pond. This study did not investigate the response of these populations to various temperatures; however, temperatures of 20-25 ${ }^{\circ} \mathrm{C}$ are adequate for maintaining culture strains isolated from these three ponds (Yamamoto, unpublished data), suggesting that these $A$. flos-aquae populations can grow over a wide range of water temperatures. In the Hirosawa-no-ike Pond, a large number of viable Microcystis colonies existed from December to mid-February in the sediment with water content of $>40 \%$ (Yamamoto, unpublished data); however, the existence of vegetative cells or akinetes of A. flos-aquae in pond sediment was unidentifiable by light microscopy. However, A. flos-aquae in the Hirosawa-no-ike Pond in February likely originated in the Osawa-no-ike Pond - this pond is a water source for the Hirosawa-no-ike Pond. Even though these two populations of $A$. flos-aquae have the same origin, their dynamics differed. In the Hirosawa-no-ike Pond, A. flos-aquae started to be excluded from plankton from April, and was absent from May to mid-October. In contrast, the A. flos-aquae population in the Osawa-no-ike Pond disappeared in mid-May-August. During these periods, other cyanoprokaryotes, particularly Anabaena and Microcystis, dominated, suggesting possible adverse effects of these genera on A. flos-aquae. The negative impact of Anabaena and Microcystis on A. flos-aquae was also verified by cyanoprokaryotes dynamics in the Osawa-no-ike Pond from late summer to autumn. Although $A$. flosaquae reappeared in September, its density remained low until the end of October when either Anabaena or Microcystis existed in high densities. However, the population of A. flos-aquae increased from November when the density of Microcystis rapidly decreased. Similarly, A. flos-aquae in the Hirosawa-no-ike Pond reappeared in mid-October and increased rapidly when the population densities of Microcystis, P. raciborskii and $R$. mediterranea decrease. Based on the roughly constant density of Anabaena from mid-September to November and rapid increase in $P$. raciborskii in late November, the period when the A. flos-aquae density increased in Hirosawa-no-ike Pond in November corresponds to decreases of Microcystis and R. mediterranea densities. In the Benkei-ike Pond, the Microcystis density increased from summer to autumn and A. flosaquae was almost undetectable during the same period. Moreover, when the Microcystis density decreased in November, that of $A$. flos-aquae started increasing. The decreases in the Microcystis density in these three ponds in late autumn are likely due to the intolerance of this genus to low water temperature (Robarts \& Zohary 1987). However, the absence or low population densities of A. flos-aquae when Microcystis dominated were common in the three ponds, suggesting that Microcystis has a probable interference effect on A. flos-aquae.

Previous studies demonstrate that the A. flos-aquae var. klebahnii population in the KU Pond is adapted to high water temperatures (Yamamoto \& Nakahara 2005, 2006). The biomass of A. flos-aquae peaked in July due to the remarkable increase after first appearing in May. Although $A$. flos-aquae sustained high population densities from June to September, the biomass observed during this period may have been suppressed by the cooccurring M. aeruginosa. In the KU Pond, Microcystis colonies were rarely detected in 2002-2005, and each summer bloom was composed solely of A. flos-aquae. Blomqvist et al. (1994) highlighted the importance of high $\mathrm{NH}_{4}{ }^{+}-\mathrm{N}$ with low $\mathrm{NO}_{3}{ }^{-}-\mathrm{N}$ for the development of non-nitrogen-fixing cyanoprokaryotes. The primary 
form of dissolved inorganic nitrogen in the KU Pond from spring to summer was $\mathrm{NH}_{4}{ }^{+}-\mathrm{N}$ since 2003 (Yamamoto \& Nakahara 2006, 2007), indicating that the nutrient environment in the pond had changed to suit for the development of non-nitrogen-fixing species since 2003, though the $\mathrm{PO}_{4}{ }^{3-}-\mathrm{P}$ concentration remained at an undetectable level. In 2005, many goldfish Carassius auratus Linnaeus, 1758 and the submerged plant Egeria densa Planch were introduced into the pond several times; thus, M. aeruginosa colonies may have been introduced into the pond simultaneously. The maximum A. flos-aquae trichome densities $\left(\mathrm{mL}^{-1}\right)$ in the KU Pond in $2002,2003,2004,2005$ and 2006 were $2.3 \times 10^{5}, 2.7$ $\times 10^{4}, 7.8 \times 10^{4}, 8.4 \times 10^{4}$ and $1.9 \times 10^{3}$, respectively (Yamamoto \& Nakahara 2006, 2007). The factor(s) responsible for the extremely low population density of A. flos-aquae in 2006 remains unknown and, thus, the possible adverse impact of $M$. aeruginosa on A. flosaquae cannot be excluded.

Based on the common phenomena among six aquatic systems, the patterns of future expansion or dynamics of $A$. flos-aquae are predicted as follows:

1) A. flos-aquae may appear as plankton in eutrophic waters where other cyanoprokaryotes are at almost undetectable levels. Marked reduction of cyanoprokaryotes, such as Anabaena and Microcystis, from the water can also open an opportunity for A. flosaquae to appear.

2) Both seasonal dynamics and annual maximum biomass of $A$. flos-aquae are affected by co-occurring cyanoprokaryotes, especially Microcystis, and their increases or appearances lead to a decrease in the $A$. flos-aquae population.

The critical factor(s) determining which variety of $A$. flos-aquae will appear was unidentified in this study. Considerable evidence exists for the negative impacts of co-occurring cyanoprokaryotes, especially Microcystis, on A. flos-aquae; however, the mechanism remains mostly unknown. For instance, whether the decreases in A. flos-aquae var. klebahnii densities before the collapse of populations in Hirosawa-no-ike Pond and Osawa-noike Pond were due to the inhibitory effect of co-occurring cyanoprokaryotes is difficult to determine, because water temperatures during this period were likely too low for growth of Anabaena and Microcystis (Robarts \& Zohary 1987). Although the temperature environment is considered adequate for growth of co-occurring cyanoprokaryotes, whether the density of Anabaena and Microcystis in Lake Yogo from spring to early summer was sufficiently high to suppress the A. flos-aquae var. flos-aquae population is open to debate. Additional research on the interspecific interaction between A. flosaquae and other cyanoprokaryotes species, and the effects of general environmental factors is necessary to elucidate the in situ population dynamics of $A$. flosaquae.

\section{ACKNOWLEDGEMENT}

Ted Knoy is appreciated for his editorial assistance.

\section{REFERENCES}

Bendschneider, K. \& R.J. Robinson. 1952. A new spectrophotometric method for the determination of nitrite in sea water. J. Mar. Res., 11: 87-96.

Blomqvist, P., A. Pettersson \& P. Hyenstrand. 1994. Ammonium-nitrogen: a key regulatory factor causing dominance of non-nitrogen-fixing cyanobacteria in aquatic systems. Arch. Hydrobiol., 132: 141-164.

Breukers, C.P.M., E.M. van Dam \& S.A. de Jong. 1997. Lake Volkerak-Zoom: a lake shifting from the clear to the turbid state. Hydrobiologia, 342/343: 367-376.

De Nobel, W.T., J. Huisman, J.L. Snoep \& L.R. Mur. 1997. Competition for phosphorus between the nitrogen-fixing cyanobacteria Anabaena and Aphanizomenon. FEMS Microbiol. Ecol., 24: 259-267.

De Nobel, W.T., H.C.P. Matthijs, E. Von Elert \& L.R. Mur. 1998. Comparison of the light-limited growth of the nitrogen-fixing cyanobacteria Anabaena and Aphanizomenon. New Phytol., 138: 579-587.

Ganf, G.G. 1983. An ecological relationship between Aphanizomenon and Daphnia pulex. Aus. J. Mar. Freshw. Res., 34: 755-773.

Gugger, M., C. Lyra, P. Henriksen, A. Couté, J.F. Humbert \& K. Sivonen. 2002. Phylogenetic comparison of the cyanobacterial genera Anabaena and Aphanizomenon. Int. J. Syst. Evol. Microbiol., 52: 1867-1880.

Hino, S. 1992. The physiological state of the phytoplankton community of three types of lakes as estimated by its adenylate energy charge. Hydrobiologia, 230: 179-192.

Holm, N.P., G.G. Ganf \& J. Shapiro. 1983. Feeding and assimilation rates of Daphnia pulex fed Aphanizomenon flos-aquae. Limnol. Oceanogr., 28: 677-687.

Ibelings, B.W., L.R. Mur \& A.E. Walsby. 1991. Diurnal changes in buoyancy and vertical distribution in populations of Microcystis in two shallow lakes. J. Plankton Res., 13: 419-436.

Jacobson, L. \& M. Halmann. 1982. Polyphosphate metabolism in the blue-green alga Microcystis aeruginosa. J. Plankton Res., 4: 481-488.

Jacobsen, B.A. 1994. Bloom formation of Gloeotrichia echinulata and Aphanizomenon flos-aquae in a shallow, eutrophic, Danish lake. Hydrobiologia, 289: 193-197.

Jiang, L., L. Yang, L. Xiao, X. Shi, G. Gao \& B. Qin. 2007. Quantitative studies on phosphorus transference occurring between Microcystis aeruginosa and its attached bacterium (Pseudomonas sp.). Hydrobiologia, 581: 161-165.

Jones, R.I. 1979. Notes on the growth and sporulation of a natural population of Aphanizomenon flos-aquae. Hydrobiologia, 62: 55-58.

Komárek, J. \& L. Kováčik. 1989. Trichome structure of four Aphanizomenon taxa (Cyanophyceae) from Czechoslovakia, with notes on the taxonomy and delimitation of the genus. Pl. Syst. Evol., 164: 47-64.

Lee, R.E. 1999. Phycology, 3rd ed. Cambridge University Press, Cambridge.

Lewin, W.C., N. Kamjunke \& T. Mehner. 2003. Phosphorus uptake by Microcystis during passage through fish guts. Limnol. Oceanogr., 48: 2392-2396.

Livingstone, D. \& G.H.M. Jaworski. 1980. The viability of akinetes of blue-green algae recovered from the sediments of Rostherne Mere. Br. Phycol. J., 15: 257-364.

Lynch, M. \& J. Shapiro. 1981. Predation, enrichment, and phytoplankton community structure. Limnol. Oceanogr., 26: 86-102. 
Mullin, J.B. \& J.P. Riley. 1955. The spectrophotometric determination of nitrate in natural waters, with particular reference to sea-water. Anal. Chim. Act., 12: 464-480.

Murphy, J.B. \& J.P. Riley. 1962. A modified single solution method for the determination of phosphate in natural waters. Anal. Chim. Act., 27: 31-36.

Nakano, S., A. Murabe, S. Tsujimura, K. Hayakawa, T. Nakajima, M. Kumagai, C. Jiao \& Z. Kawabata. 2003. Dominance of Microcystis with special reference to carbon availability in lake water. Microb. Environ., 18: 38-42.

Nizan, S., C. Dimentman \& M. Shilo. 1986. Acute toxic effects of the cyanobacterium Microcystis aeruginosa on Daphnia magna. Limnol. Oceanogr., 31: 497-502.

Paerl, H.W., P.T. Bland, N.D. Bowles \& M.E. Haibach. 1985. Adaptation to high-intensity, low-wavelength light among surface blooms of the cyanobacterium Microcystis aeruginosa. Appl. Environ. Microbiol., 49: 1046-1052.

Pechar, L. 1992. Water blooms of Aphanizomenon flos-aquae. An ecological study of fish pond population. Arch. Hydrobiol./Suppl., 90: 339-418.

Preston, T., W.D.P., Stewart \& C.S. Reynolds. 1980. Bloomforming cyanobacterium Microcystis aeruginosa overwinters on sediment surface. Nature, 288: 365-367.

Pollingher, U., O. Hadas, Y.Z. Yacobi, T. Zohary \& T. Berman. 1998. Aphanizomenon ovalisporum (Forti) in Lake Kinneret, Israel. J. Plankton Res., 20: 1321-1339.

Robarts, R.D. \& T. Zohary. 1987. Temperature effects on photosynthetic capacity, respiration, and growth rates of bloom-forming cyanobacteria. N. Z. J. Mar. Freshw. Res., 21: 391-399.

Sagi, T. 1966. Determination of ammonia in sea water by the indophenol method and its application to the coastal and off-shore waters. Oceanogr. Mag., 18: 43-51.

Shapiro, J. 1997. The role of carbon dioxide in the initiation and maintenance of blue-green dominance in lakes. Freshwat. Biol., 37: 307-323.

Received: July 2008

Accepted: December 2008
Takamura, N., T. Iwakuma \& M. Yasuno. 1987. Uptake of ${ }^{13} \mathrm{C}$ and ${ }^{15} \mathrm{~N}$ (ammonium, nitrate and urea) by Microcystis in Lake Kasumigaura. J. Plankton Res., 9: 151-165.

Takano, K. \& S. Hino. 2000. Effect of temperature and soluble reactive phosphorus on abundance of Aphanizomenon flosaquae (Cyanophyceae). Phycol. Res., 48: 9-13.

Tsujimura, S., K. Ishikawa \& H. Tsukada. 2001. Effect of temperature on growth of the cyanobacterium Aphanizomenon flos-aquae in Lake Biwa and Lake Yogo. Phycol. Res., 49: 275-280.

Tsujimura, S. 2004. Water management of Lake Yogo targeting internal phosphorus loading. Lakes Reserv. Res. Manage., 9: 171-179.

Tsukada, H., S. Tsujimura \& H. Nakahara. 2006. Seasonal succession of phytoplankton in Lake Yogo over 2 years: effect of artificial manipulation. Limnology, 7: 3-14.

Uehlinger, U. 1981. Experimental studies on the autecology of Aphanizomenon flos-aquae. Arch. Hydrobiol./Suppl., 60 (Algol. Stud., 28): 260-288.

Watanabe, M. 1991. Studies on the planktonic blue-green algae 3. Some Aphanizomenon species in Hokkaido, Northern Japan. Bull. Nat. Sci. Mus. Tokyo, Ser. B, 17: 141-150.

Yamamoto, Y. \& H. Nakahara. 2005. The formation and degradation of cyanobacterium Aphanizomenon flos-aquae blooms: the importance of $\mathrm{pH}$, water temperature, and day length. Limnology, 6: 1-6.

Yamamoto, Y. \& H. Nakahara. 2006. Importance of interspecific competition in the abundance of Aphanizomenon flos-aquae (Cyanophyceae). Limnology, 7: 163-170.

Yamamoto, Y. \& H. Nakahara. 2007. Factors affecting the fluctuation of akinete and heterocyst numbers of Aphanizomenon flos-aquae (Cyanobacteria) population. Algol. Stud., 125: 79-96. 